\title{
STRESS DISTRIBUTION IN A PLATE WITH A HOLES ALONG THE DIAGONAL DISTRIBUTION UNDER PLANE BIAXIAL LOAD
}

\author{
KONIECZNY Mateusz ${ }^{1 *}$, ACHTELIK Henryk ${ }^{2}$, GASIAK Grzegorz ${ }^{3}$

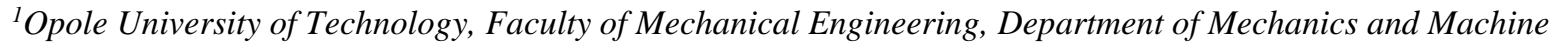 \\ Design, St. Mikolajczyka 5,45-271 Opole, Poland, e-mail: mateuszmarcinkonieczny@wp.pl \\ ${ }^{2}$ Opole University of Technology, Faculty of Mechanical Engineering, Department of Mechanics and Machine \\ Design, St. Mikotajczyka 5, 45-271 Opole, Poland, e-mail: h.achtelik@po.edu.pl \\ ${ }^{3}$ Opole University of Technology, Faculty of Mechanical Engineering, Department of Mechanics and Machine \\ Design, St. Mikołajczyka 5, 45 - 271 Opole, Poland, e-mail: g.gasiak@po.edu.pl
}

\begin{abstract}
The object of the work is numerical analysis of the state of stress in the plate with holes made along its diagonal, which was subjected to a plane load. The plate was subjected to biaxial loading both in the direction of the $y$ axis, i.e. $P_{y}=+/-100 \mathrm{kN}$ and the $\mathrm{z}$ axis, i.e. $\mathrm{P}_{\mathrm{z}}=+/-100 \mathrm{kN}$. It was shown that the highest concentration of reduced stress occurred in a plate with two holes in the case of load in the form of pure shear $\left(\mathrm{P}_{\mathrm{y}}=-100 \mathrm{kN}, \mathrm{P}_{\mathrm{z}}=\right.$ $100 \mathrm{kN}$ ). The pure shear load case proved to be the least favourable from the point of view of straining the plate with holes.
\end{abstract}

KEYWORDS: Plate, holes, reduced stresses, stress concentration factor, biaxial load, numerical calculations

\section{Introduction}

In engineering objects, plate construction elements containing a number of holes made for operational reasons are often used [1-6]. Such constructions are used in chemical apparatus such as e.g. heat exchanger tube sheets. [7,8].

Calculating plates with a circular hole was done by, among others J. Ryś and M. Życzkowski [9]. They analyzed a circular-symmetrical plate of any size, loaded with pressure at the edges for a case of plastic material reinforcement. The analytical formulas given in the paper allow approximate the state of stress and calculate the values of stresses and deformations occurring in the considered plate. Whereas J. Ryś [10] considers a springy unlimited plate with three holes loaded with pressure. The result of the work are generalized analytical relationships that allow to determine the state of stress in the plate, its load capacity, displacement and rigidity of the plate for any hole radii and any distance. The scientific works cited above indicate a large discrepancy between the results obtained when analyzing models based on the equations of the theory of elasticity, and the results obtained using the formulas and requirements of the Office of Technical Inspection [11].

The impact of elastic stress fields in perforated elements (discs and plates) assessed by analytical and experimental methods has led to the development of practical design methods based on the finite element method [12-14].

The purpose of the work is numerical analysis of the state of stress in the plate with holes along its diagonal, which has been subjected to a plane load. The effect of this analysis is to examine the effect of adjacent holes on the stress concentration in the plate. 


\section{$2 \quad$ Plate geometry and way of loading}

For calculating the state of stress, case A: a plate with one central circular hole of the following dimensions was adopted: length $\mathrm{L}=300 \mathrm{~mm}$, width $\mathrm{B}=300 \mathrm{~mm}$, thickness $\mathrm{g}=10$ $\mathrm{mm}$, hole diameter $\mathrm{d}_{1}=50 \mathrm{~mm}$ (Fig. 1a); case B: a plate with two circular holes of the following dimensions: length $\mathrm{L}=300 \mathrm{~mm}$, width $\mathrm{B}=300 \mathrm{~mm}$, thickness $\mathrm{g}=10 \mathrm{~mm}$, hole diameter $\mathrm{d}_{1}=$ $\mathrm{d}_{2}=50 \mathrm{~mm}$, distance between the hole $1_{1}=10 \mathrm{~mm}$ (Fig. $1 \mathrm{~b}$ ) and case C: a plate with three circular holes with the following dimensions: length $\mathrm{L}=300 \mathrm{~mm}$, width $\mathrm{B}=300 \mathrm{~mm}$, thickness $\mathrm{g}=10 \mathrm{~mm}$, hole diameter $\mathrm{d}_{1}=\mathrm{d}_{2}=\mathrm{d}_{3}=50 \mathrm{~mm}$, distance between the holes $\mathrm{l}_{1}=\mathrm{l}_{2}==10 \mathrm{~mm}$ (Fig. 1c). It was assumed that the plate has a plane state of stress. The following plate boundary conditions were adopted (Fig. 1): CD and DE sides articulated; EF and FC free sides.

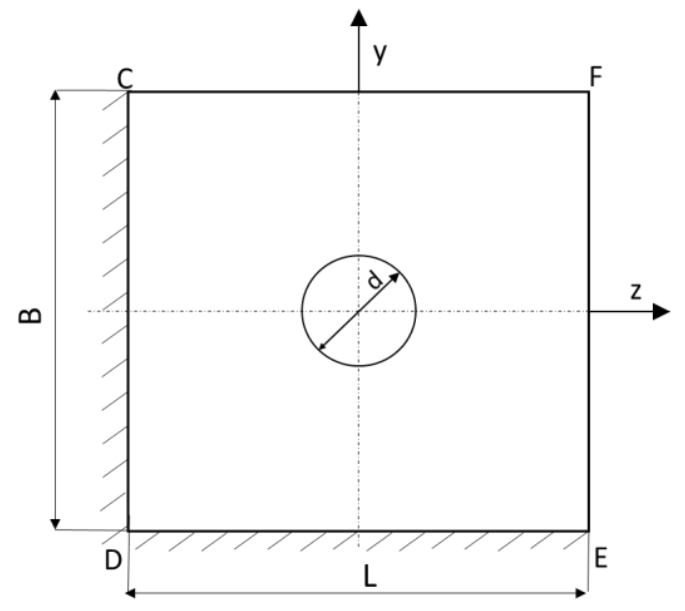

a)

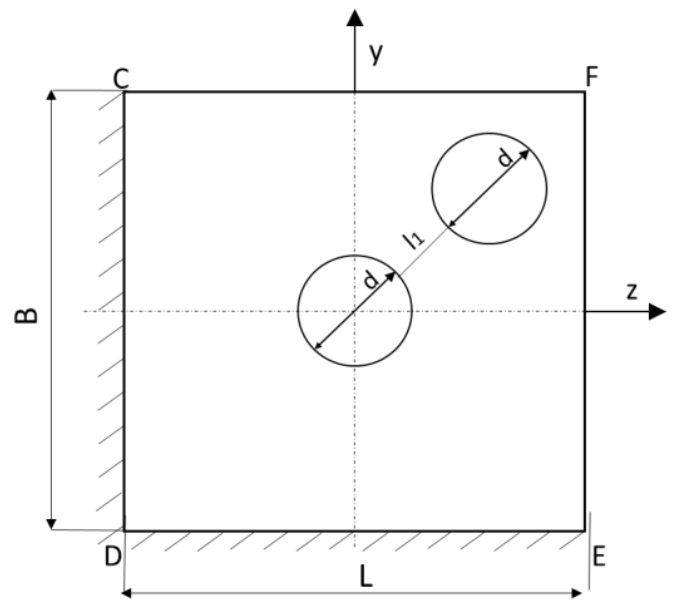

b)

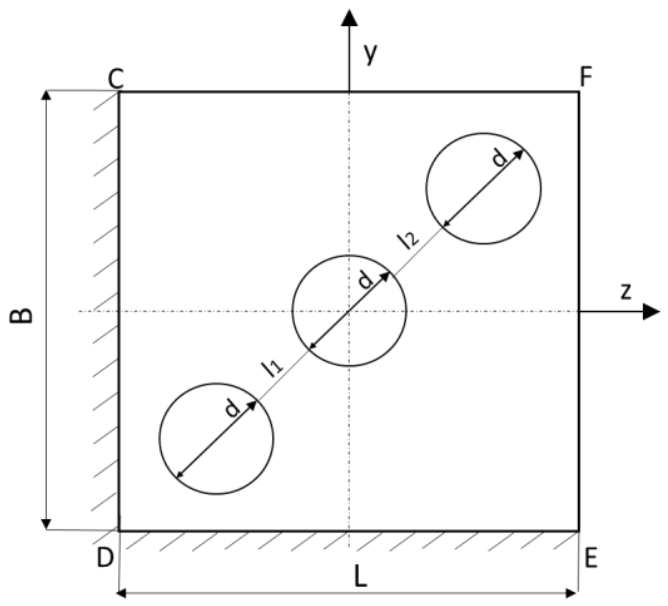

c)

Fig. 1 Plate geometry: a) with a centrally located circular hole; b) with two circular holes; c) with three circular holes.

Steel sheet in the S235JR grade according to [PN - EN 1027-1] with the following mechanical parameters (Table 1) and material parameters (Table 2) was adopted as the plate material. 
Table 1 Strength properties of S235JR steel

\begin{tabular}{|c|ccc|}
\hline $\begin{array}{c}\text { Yield strength } \\
\mathbf{R e}[\mathrm{MPa}]\end{array}$ & $\begin{array}{c}\text { Tensile strength } \\
\mathbf{R m}[\mathrm{MPa}]\end{array}$ & $\begin{array}{c}\text { Young modulus } \\
\mathbf{E}[\mathrm{MPa}]\end{array}$ & $\begin{array}{c}\text { Poisson ratio } \\
\mathbf{v}[-]\end{array}$ \\
\hline 235 & $360-510$ & 200000 & 0.3 \\
\hline
\end{tabular}

Table 2 Chemical composition of S235JR steel [\%]

\begin{tabular}{|c|cccc|}
\hline C & Mn & S & N & P \\
\hline 0,2 & 1,4 & 0,040 & 0,009 & 0,040 \\
\hline
\end{tabular}

The plate with the holes shown in Fig. 1a - 1c is subjected to a plane biaxial loading in the form of: case A: extension along $\mathrm{z}$ axis and $\mathrm{y}$ axis, i.e. $\mathrm{P}_{\mathrm{z}}=100 \mathrm{kN}$ and $\mathrm{P}_{\mathrm{y}}=100 \mathrm{kN}$ (Fig. $4 \mathrm{a}$, 5a, 6a); case $\mathrm{B}$ : extension along $\mathrm{z}$ axis and compression along y axis, i.e. $\mathrm{P}_{\mathrm{z}}=100 \mathrm{kN}$ and $\mathrm{P}_{\mathrm{y}}=$ $-100 \mathrm{kN}$ (Fig. 4c, 5c, 6c); case $\mathrm{C}$ : compression along $\mathrm{z}$ axis and y axis, i.e. $\mathrm{P}_{\mathrm{z}}=-100 \mathrm{kN}$ and $\mathrm{P}_{\mathrm{y}}$ $=-100 \mathrm{kN}$ (Fig. 4e, 5e, 6e). The state of stress in the plate is a complex. The von Mises hypothesis was used to determine the reduced stress in plate, in form of [15]:

$$
\sigma_{\text {red }}=\sqrt{\sigma_{\mathrm{y}}^{2}+\sigma_{\mathrm{z}}^{2}-\sigma_{\mathrm{y}} \sigma_{\mathrm{z}}+3 \tau_{\mathrm{yz}}^{2}}
$$

where $\sigma_{\text {red }}-$ reduces stress $[\mathrm{MPa}] ; \sigma_{\mathrm{y}}, \sigma_{\mathrm{z}}$ - stress along y axis and $\mathrm{z}$ axis $[\mathrm{MPa}] ; \tau_{\mathrm{yz}}-$ tangential stress. [MPa].

\section{Determination of state of stress by the finite element method}

\subsection{Test calculations}

The subject of the test calculations was the stress distribution in a plate with a central circular hole of dimensions; length $\mathrm{L}=300 \mathrm{~mm}$; width $\mathrm{B}=300 \mathrm{~mm}$; thickness $\mathrm{g}=10 \mathrm{~mm}$; bore diameter $\mathrm{d}=50 \mathrm{~mm}$ as in the case of A, made of steel sheet in the S235JR grade and subjected to biaxial loading, i.e. tension along the $\mathrm{z}$ axis and compression along the $\mathrm{y}$ axis with the force $\mathrm{P}_{\mathrm{z}}=600$ $\mathrm{kN}$ and $\mathrm{P}_{\mathrm{y}}=-600 \mathrm{kN}$ as in the case of $\mathrm{B}$. Test calculations were carried out using the Franc $2 \mathrm{dl}$ software [16] and ANSYS software [17]. They are intended for advanced numerical calculations using the finite element method (FEM). The plate body was modeled in the first case using flat finite elements (2D) (Fig. 2a), in the second case using spatial finite elements (3D) (Fig. 2b). The calculation model contained the total number of finite elements 110580, while the total number of nodes was 514363. The plate had 5 layers of finite elements.

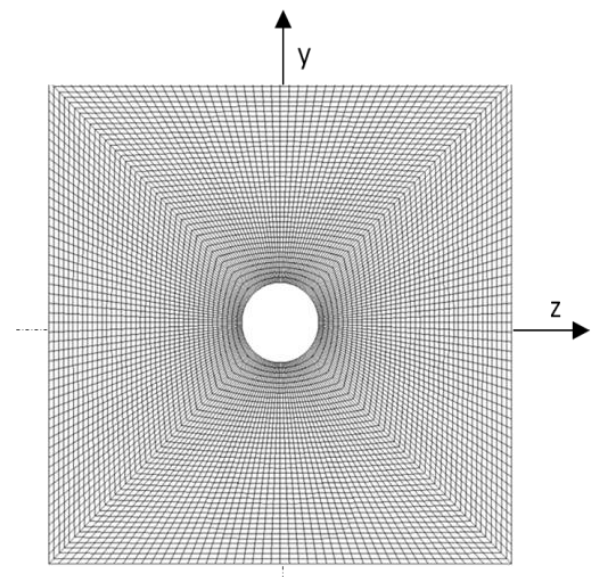

a)

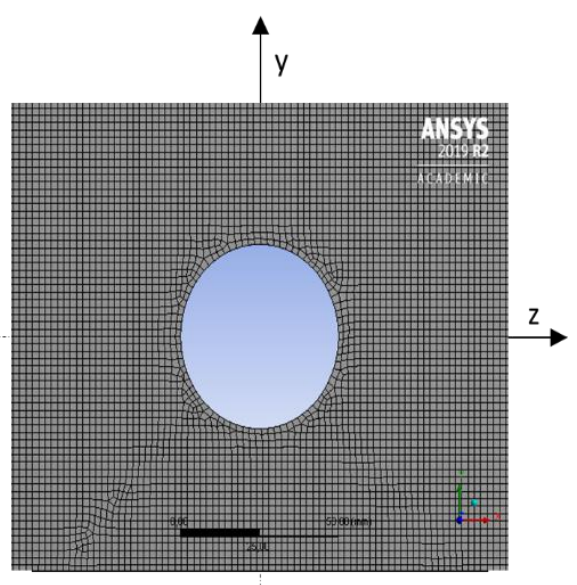

b)

Fig. 2 Division into finite elements of a plate with a centrally located circular hole:

a) according to the Franc $2 \mathrm{dl}$ program; b) according to the ANSYS program 
For example, Fig. 3 shows the distribution of reduced stress $\sigma_{\text {red }}$ given in MPa and calculated according to the Huber-Mises hypothesis around a hole in the plate with one central hole with the dimensions given in the case of $\mathrm{A}$ and subjected to biaxial loading, as the case of $\mathrm{B}$.

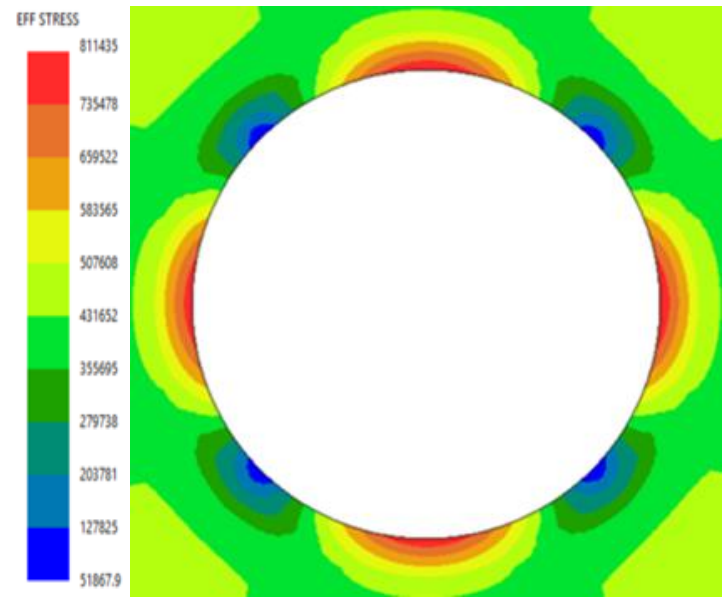

a)

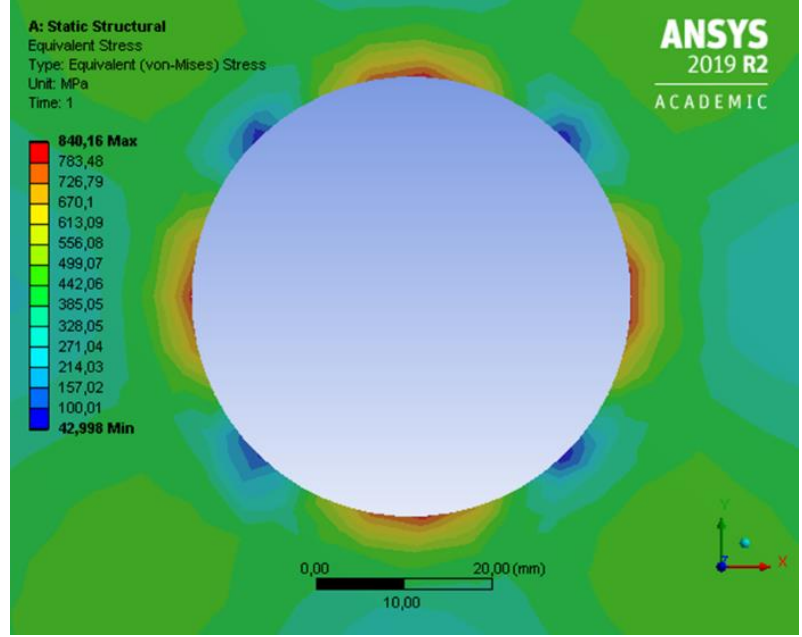

b)

Fig. 3 Distribution of reduced stress $\sigma_{\text {red }}$ according to the Huber-Mises hypothesis around a hole in the plate with one central hole with dimensions: length $\mathrm{L}=300 \mathrm{~mm}$, width $\mathrm{B}=300$ $\mathrm{mm}$, thickness $\mathrm{g}=10 \mathrm{~mm}$, bore diameter $\mathrm{d}_{1}=50 \mathrm{~mm}$ and subjected to biaxial loading, i.e. tension along the $\mathrm{z}$ axis and compression along the $\mathrm{y}$ axis with the force $\mathrm{P}_{\mathrm{z}}=600 \mathrm{kN}$ and $\mathrm{P}_{\mathrm{y}}=$ $-600 \mathrm{kN}$ : a) according to the Femap program, where $\sigma_{\text {red } \max }=811.4 \mathrm{MPa}$; b) according to the ANSYS program, where $\sigma_{\text {red } \max }=840.10 \mathrm{MPa}$

It follows from the above that for biaxial loading (case B) of the plate with a central circular hole, in this case the value of reduced stress $\sigma_{\text {red }}$ obtained according to the Franc $2 \mathrm{dl}$ program was $\sigma_{\text {red } \max }=811.4 \mathrm{MPa}$, while according to the ANSYS program it was $\sigma_{\text {red } \max }=840.16 \mathrm{MPa}$. The percentage difference in this case was $-3.5 \%$. This difference is small, and therefore the numerical calculations of the stress distribution were carried out using the ANSYS program.

The purpose of the test calculations was to show which commercially available finite element method program is more effective for the design of plate structures by engineers. The comparison of the obtained calculation results is to help engineers in choosing the appropriate calculation tool, which is currently the commonly used finite element method. The result of this comparison was to show that the ANSYS program is more effective because it enables a triaxial analysis of the state of stress of plates with holes, which is very important when searching for the location of stress concentration in the area of the plate hole. Literature studies also show [18 -23] that it is a universal program and more adapted to this type of calculations.

\subsection{Basic calculations}

The subject of basic numerical calculations was the stress distribution in plate with a one hole, plate with a two hole and plate with a three hole, whose parameters: dimension, support method and load method are described in section 2 in this paper. Numerical calculations were carried out using finite element ANSYS software [17]. The plate was modeled using spatial finite elements (3D) with a quadratic shape function (Fig. 3). The calculation model in the form of plate with one hole contained the total number of finite elements 110580 , while the total number of nodes was 514363 and 5 layers of finite elements, plate with two holes contained the total number of finite elements 107950, while the total number of nodes was 502849 and 5 
layers of finite elements however plate with three holes contained the total number of finite elements 106330, while the total number of nodes was 496032 and 5 layers of finite elements.

Figure 4 shows the load method and reduced stress distributions $\sigma_{\text {red }}$ in plates with a central circular hole loaded according to the methods described in point 2 . The reduced stress distributions given in MPa were determined using the Huber-Mises hypothesis.

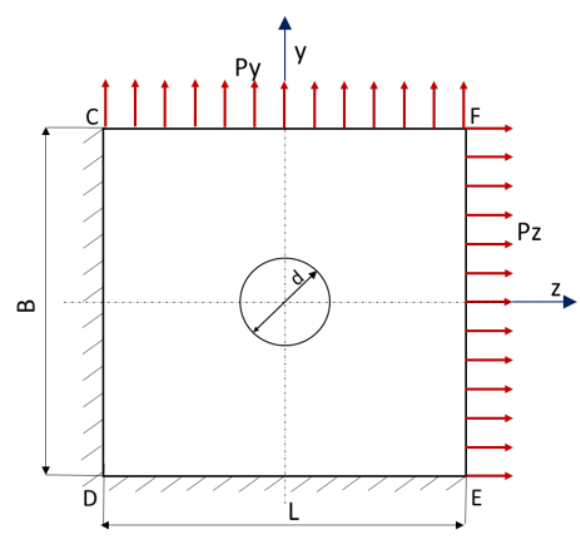

a)

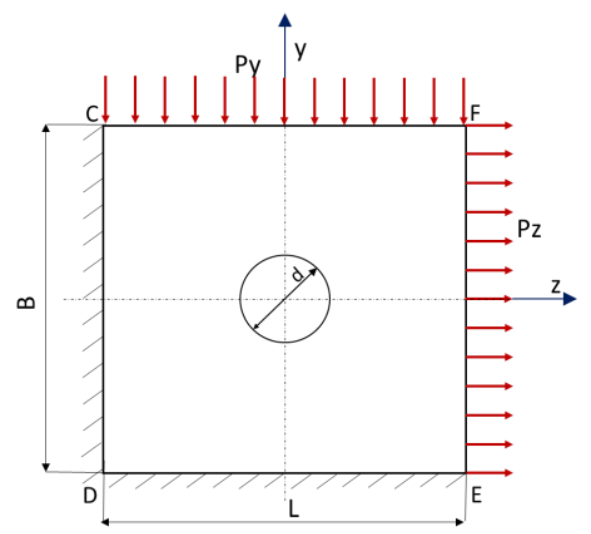

c)

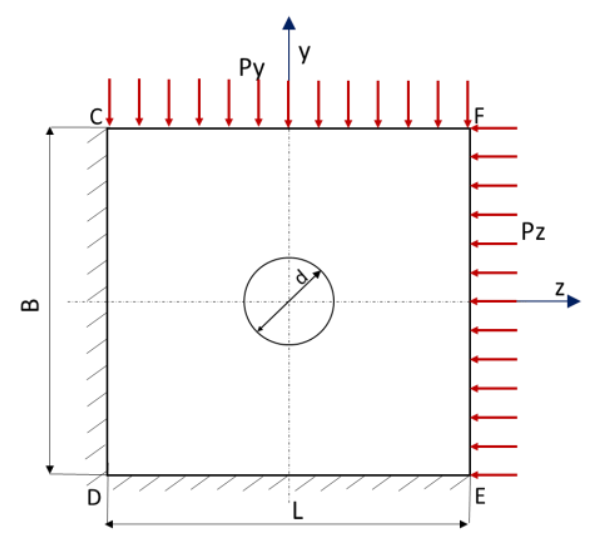

e)

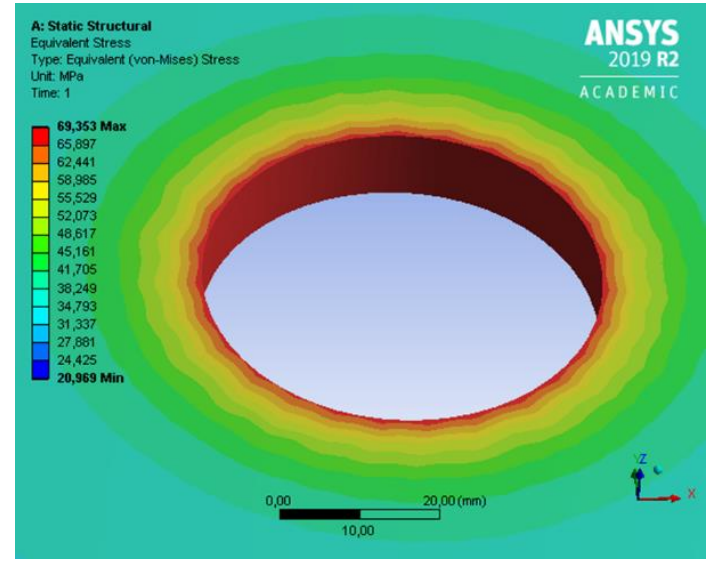

b)

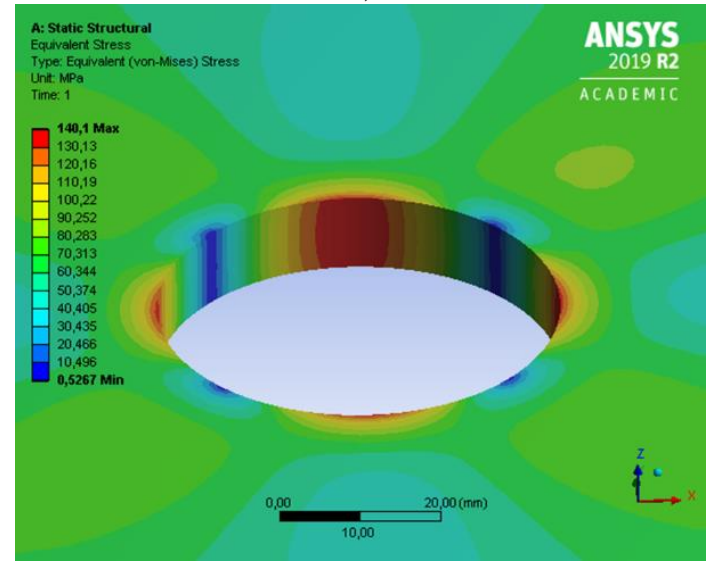

d)

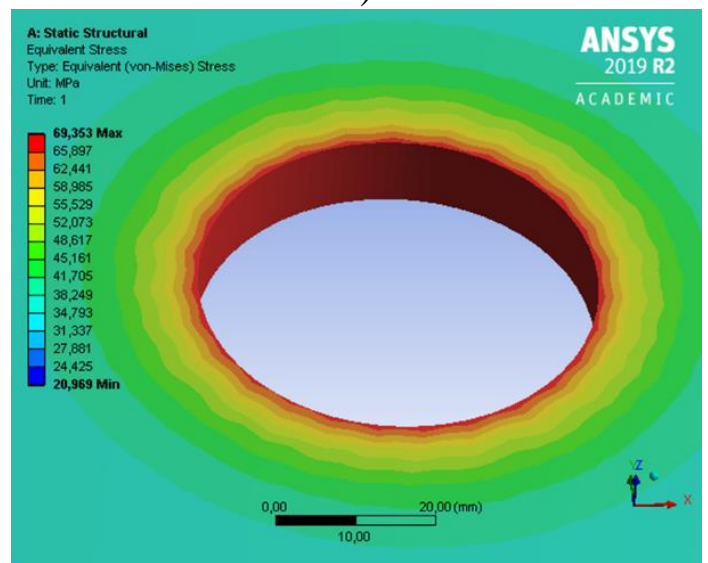

f)

Fig. 4 Way of loading the plate and distribution of reduced stress in plate with circular hole: a) $\mathrm{P}_{\mathrm{z}}=100 \mathrm{kN}, \mathrm{P}_{\mathrm{y}}=100 \mathrm{kN}$; b) $\sigma_{\text {red } \max }=69.35 \mathrm{MPa}$; c) $\mathrm{P}_{\mathrm{z}}=100 \mathrm{kN}, \mathrm{P}_{\mathrm{y}}=-100 \mathrm{kN}$; d) $\sigma_{\text {red } \max }$ $=140.10 \mathrm{MPa}$; e) $\mathrm{P}_{\mathrm{z}}=-100 \mathrm{kN}, \mathrm{P}_{\mathrm{y}}=-100 \mathrm{kN}$; f) $\sigma_{\text {red } \max }=69.35 \mathrm{MPa}$ 
Figure 5 presents the load method and reduced stress distributions $\sigma_{\text {red }}$ in plates with two circular holes loaded according to the methods described in point 2. The reduced stress distributions given in MPa were determined using the Huber-Mises hypothesis

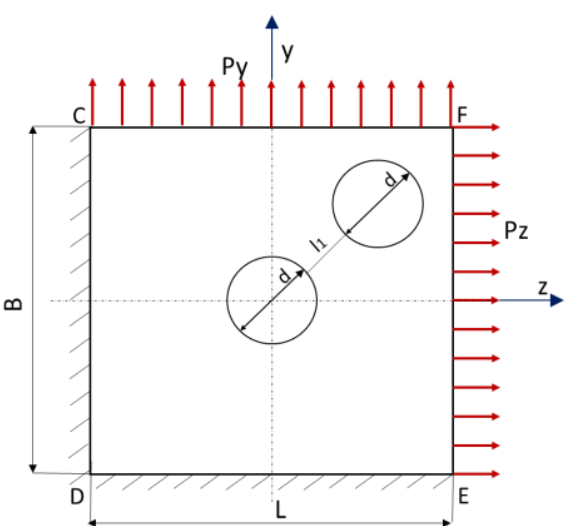

a)

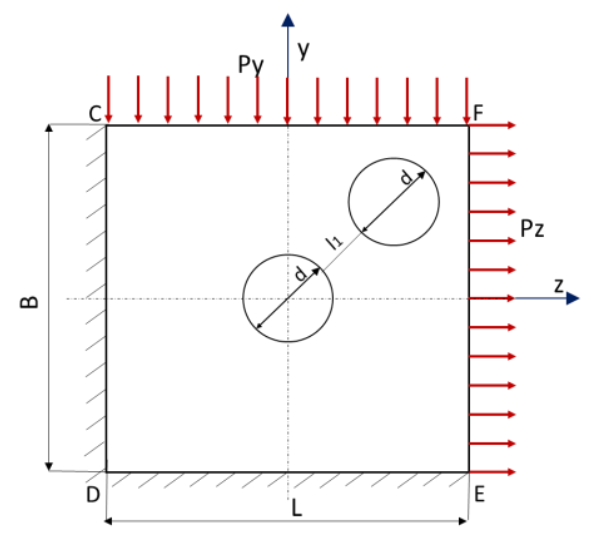

c)

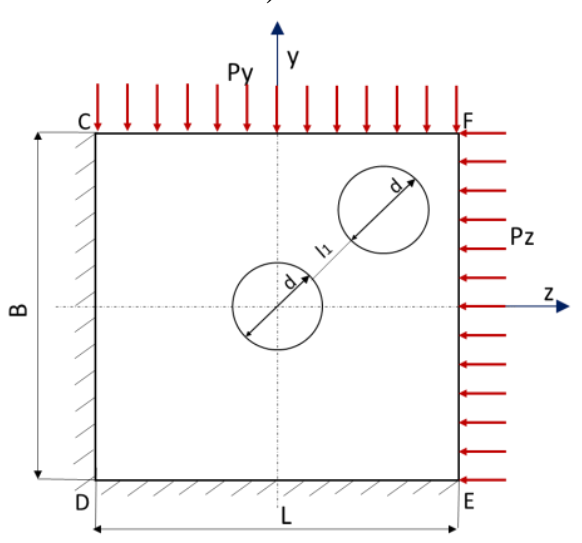

e)

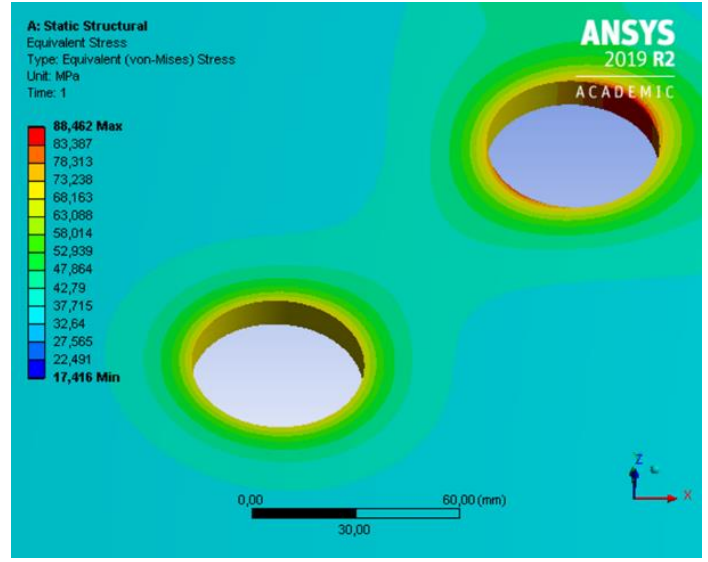

b)

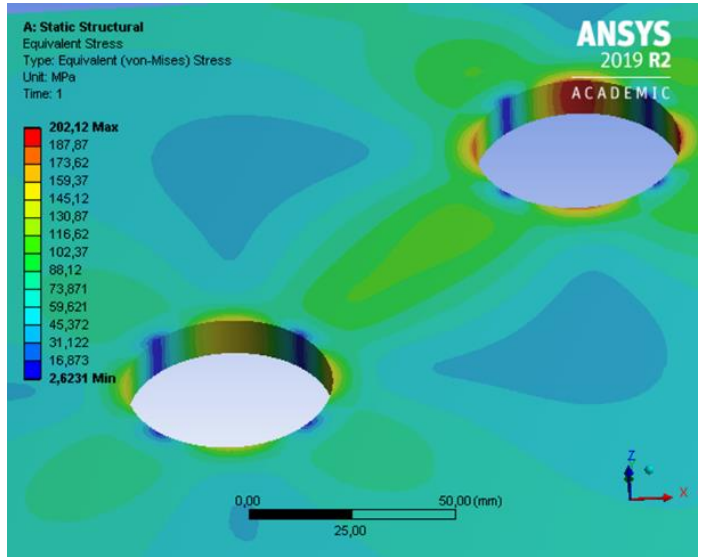

d)

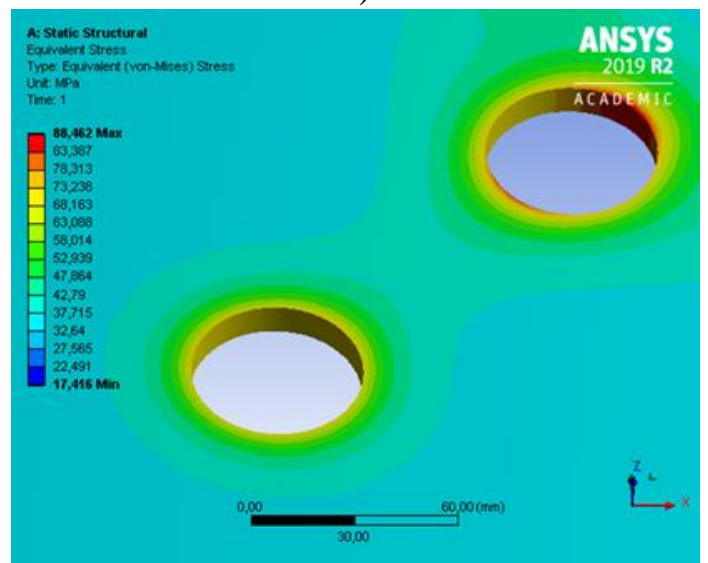

f)

Fig. 5 Way of loading the plate and distribution of reduced stress in plate with two circular hole: a) $\mathrm{P}_{\mathrm{z}}=100 \mathrm{kN}, \mathrm{P}_{\mathrm{y}}=100 \mathrm{kN}$; b) $\sigma_{\text {red } \max }=88.46 \mathrm{MPa}$; c) $\mathrm{P}_{\mathrm{z}}=100 \mathrm{kN}, \mathrm{P}_{\mathrm{y}}=-100 \mathrm{kN}$; d) $\sigma_{\text {red } \max }$ $=202.12 \mathrm{MPa}$; e) $\mathrm{P}_{\mathrm{z}}=-100 \mathrm{kN}, \mathrm{P}_{\mathrm{y}}=-100 \mathrm{kN}$; f) $\sigma_{\text {red } \max }=88.46 \mathrm{MPa}$

Figure 6 shows the load method and the reduced stress distributions $\sigma_{\text {red }}$ in plates with three circular hole loaded according to the methods described in point 2. The reduced stress distributions given in MPa were determined using the Huber-Mises hypothesis. 


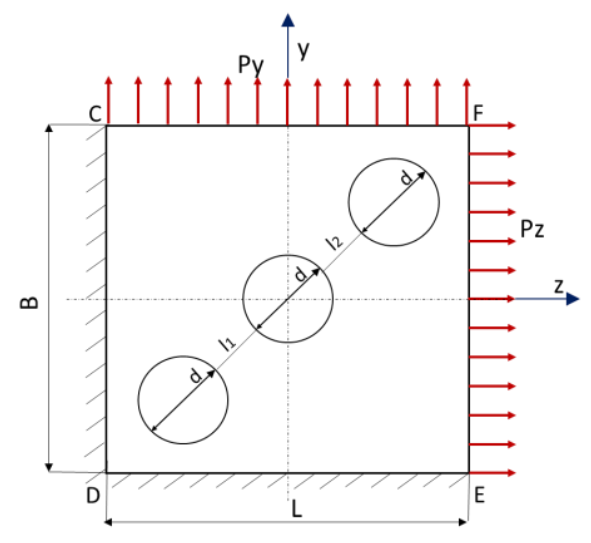

a)

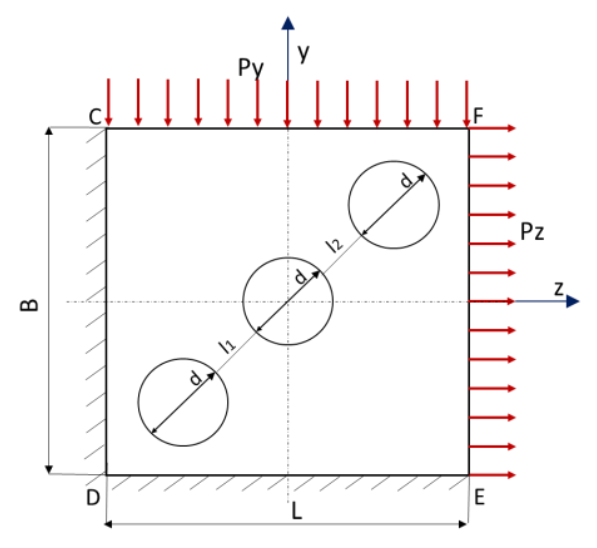

c)

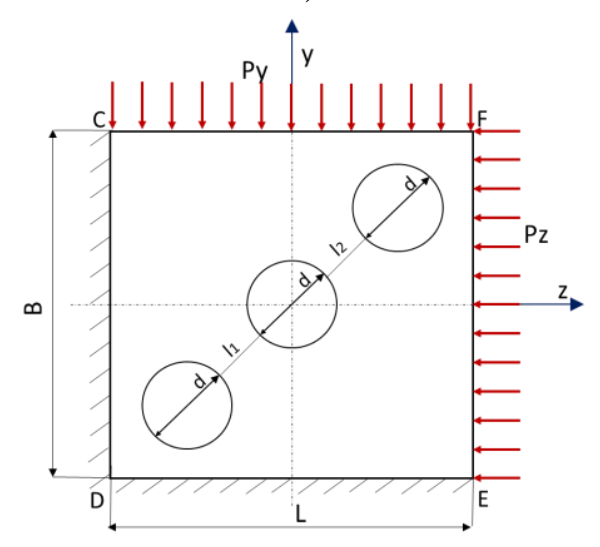

e)

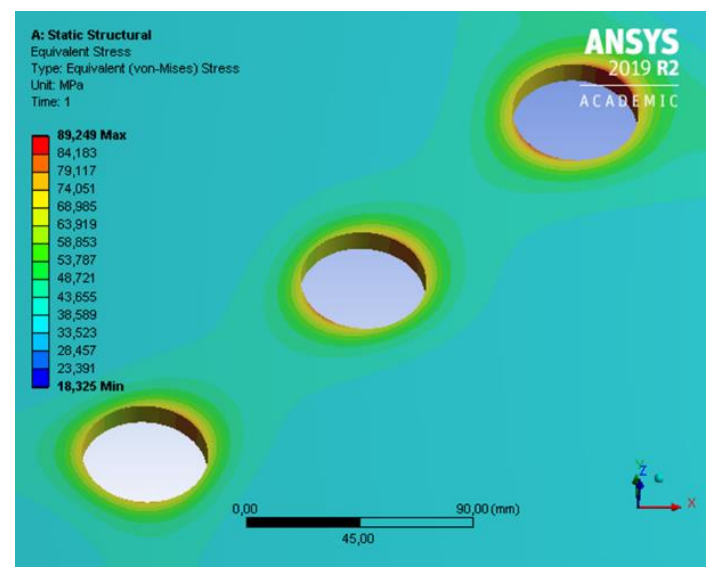

b)

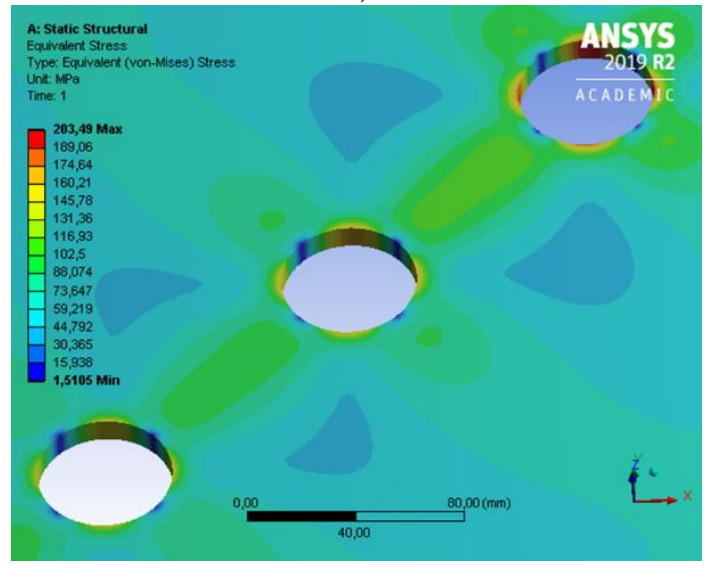

d)

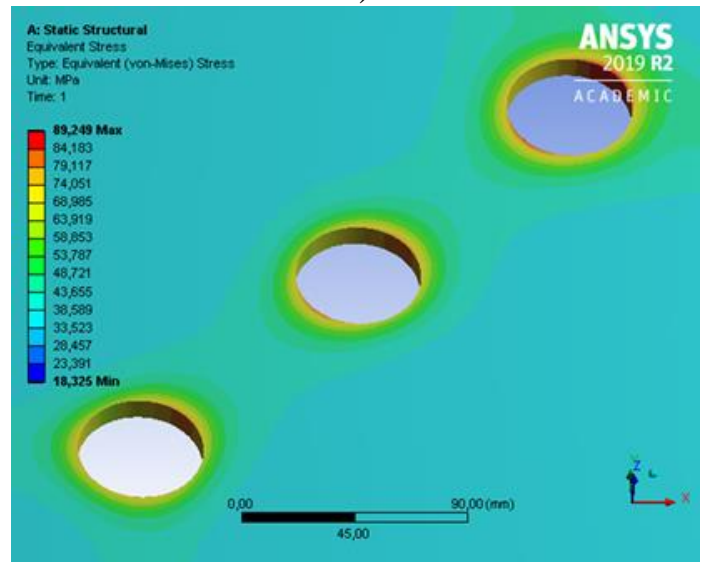

f)

Fig. 6 Way of loading the plate and distribution of reduced stress in plate with three circular hole: a) $\mathrm{P}_{\mathrm{z}}=100 \mathrm{kN}, \mathrm{P}_{\mathrm{y}}=100 \mathrm{kN}$; b) $\sigma_{\text {red } \max }=89.25 \mathrm{MPa}$; c) $\mathrm{P}_{\mathrm{z}}=100 \mathrm{kN}, \mathrm{P}_{\mathrm{y}}=-100 \mathrm{kN}$; d) $\sigma_{\text {red } \max }=203.49 \mathrm{MPa}$; e) $\mathrm{P}_{\mathrm{z}}=-100 \mathrm{kN}, \mathrm{P}_{\mathrm{y}}=-100 \mathrm{kN}$; f) $\sigma_{\text {red } \max }=89.25 \mathrm{MPa}$

Stress concentration is defined as the localization of high stresses due to the irregularities present in the components and abrupt changes of the cross section. In order to consider the effect of stress concentration and find out localized stress a factor called stress concentration factor is used. It is denoted by $\mathrm{k}$ [24]. The ratio of maximum stress at the cut out edge to nominal stress is called stress concentration factor. The magnitude of the stress concentration caused by the occurrence of geometric stress concentrator in this case, i.e. the circular holes, in each body is measured by the stress concentration factor $\mathrm{k}$, which is determined from the formula: 


$$
\mathrm{k}=\frac{\sigma_{\text {red max }}}{\sigma_{\text {red nom }}}
$$

where: $\mathrm{k}$ - stress concentration factor [-]; $\sigma_{\text {red max }}-$ maximum reduced stress [MPa]; $\sigma_{\text {red nom }}$ nominal reduced stress occurring in the plate without a hole calculated according to equation (1) $[\mathrm{MPa}]$.

The application of stress concentration factor $\mathrm{k}$ is aimed at demonstrating the percentage increase in reduced stress in the plate in the presence of holes made in it for structural or technological reasons. It is assumed that the holes in the plate are smooth without any notches. In order to perform a comparative analysis of the state of stress in a plate weakened by holes, it is convenient to use a dimensionless value of reduced stress by introducing a stress concentration factor $\mathrm{k}$.

\section{$4 \quad$ Results analysis}

Due to the fact that the nominal reduced stress in the plate outside the hole zone in the case of biaxial tension (case A) and biaxial compression (case C) was $\sigma_{\text {red nom }}=30.3 \mathrm{MPa}$, and in the case of tension and compression (pure shear case - case B) it was $\sigma_{\text {red nom }}=37.7 \mathrm{MPa}$, therefore the stress concentration factor $\mathrm{k}$ around the circular hole for pure shear is equal to: for a one circular hole $\mathrm{k}=3.72$ and for a two circular hole $\mathrm{k}=5.36$ and for a three circular hole $\mathrm{k}=5.40$.

Table 3 gives a summary of the results of the maximum reduced stress $\sigma_{\text {red max }}$ according to the Huber-Mises hypothesis and the stress concentration factor $\mathrm{k}$ in the plate with a circular holes subjected to a biaxial load.

Table 3 The results of the calculation of the maximum reduced stress $\sigma_{\text {red max }}$ and the stress concentration factor $\mathrm{k}$ in the plate with a circular holes at biaxial load $\mathrm{P}_{\mathrm{z}}$ and $\mathrm{P}_{\mathrm{y}}$.

\begin{tabular}{|c|c|c|c|c|c|c|c|}
\hline \multicolumn{8}{|c|}{ Maximum reduced stress $\sigma_{\text {red }}$ max and the stress concentration factor $k$} \\
\hline \multicolumn{2}{|c|}{ Load } & \multicolumn{2}{|c|}{ One circular hole } & \multicolumn{2}{|c|}{ Two circular hole } & \multicolumn{2}{|c|}{ Three circular hole } \\
\hline $\mathrm{P}_{\mathrm{z}}[\mathrm{kN}]$ & $\mathrm{P}_{\mathrm{y}}[\mathrm{kN}]$ & $\begin{array}{c}{ }^{1)} \sigma_{\text {red } \max } \\
{[\mathrm{MPa}]}\end{array}$ & 2) $\mathrm{k}[-]$ & $\begin{array}{c}{ }^{1)} \sigma_{\text {red max }} \\
{[\mathrm{MPa}]}\end{array}$ & 2) $\mathrm{k}[-]$ & $\begin{array}{c}{ }^{1)} \sigma_{\text {red max }} \\
{[\mathrm{MPa}]}\end{array}$ & 2) $\mathrm{k}[-]$ \\
\hline 100 & 100 & 69.35 & 2.29 & 88.46 & 2.92 & 89.25 & 2.95 \\
\hline 100 & -100 & 140.10 & 3.72 & 202.12 & 5.36 & 203.49 & 5.40 \\
\hline-100 & -100 & 69.35 & 2.29 & 88.46 & 2.92 & 89.25 & 2.95 \\
\hline
\end{tabular}

The obtained calculation results (Table 3 ) indicate that the highest concentration of reduced stress occurred in a plate with three holes, subjected to the load as in case of B, which it was respectively $\sigma_{\text {red } \max }=203.49 \mathrm{MPa}$ (Fig. 6c, 6d).

The geometry of the distribution of holes in the plate significantly affects the nature of the stress distribution. In addition, the method of loading plates with holes also affects the value of stress concentration. The largest value of stress concentration coefficient $k$ occurred in the case of load in the form of pure shear (tension in the direction of one axis and compression in the direction of the other axis), i.e. $\mathrm{k}=3.72$.

Table 3 shows that in the presence of a second hole in the case of pure shear, the stress concentration factor increased to $\mathrm{k}=5.36$. When there are three holes in the plate, the stress concentration factor increased slightly, i.e. $\mathrm{k}=5.40$. 
It follows from the above that under the above-described loading conditions for the adopted geometry of the plate, the first and second holes substantially affect the stress concentration around the holes. However, adding another hole slightly changes the stress concentrator, i.e. an increase of approximately $1 \%$.

\section{CONCLUSION}

Based on the numerical calculations of the state of reduced stress in a plates with holes subjected to biaxial loading, the following conclusions can be drawn:

1) It was demonstrated that the highest concentration of reduced stress occurred in a plate with two holes in the case of pure shear loading;

2) For plate loading in the form of pure shear, i.e. $P_{z}=100 \mathrm{kN}$ and $P_{y}=-100 \mathrm{kN}$, the stress concentration factor was: $\mathrm{k}=3.72$ in the presence of one hole, $\mathrm{k}=5.36$ in the case of two holes and $\mathrm{k}=5,40$ if there are three holes;

3) The pure shear load case proved to be the least favorable in terms of plate effort;

4) Engineers are recommended to treat a plate with holes biaxially loaded, i.e. extension and compression (pure shear case) in a special way by adopting an appropriate safety factor;

5) The proposed finite element ANSYS program allows the determination of stress values along the thickness of the plate, especially near the hole.

\section{REFERENCES}

[1] Niezgodziński, M. E. "Obliczanie den sitowych zbiorników ciśnieniowych”, Przegląd Mechaniczny 3, 1973. (in Polish)

[2] Baik, S. C., Oh, K. H., Lee, D. N. "Analysis of the deformation of a perforated plates with sguare arrays of holes“, Nuclear Engineering and Design 231, pp. 219 - 233, 2004.

[3] Lee, Y-Ch., Chen, F-K. "Yield criterion for a perforated sheed with a uniform triangular pattern of round holes and a low ligament ratio“, Journal of Materials Processing Technology 103, pp. 353 - 361, 2000.

[4] Bhattacharya, A., Venkat, R. V. "Yield Surfaces for Perforated Plates with Square Arrays of Holes“, Nuclear Engineering and Design 231, pp. 219 - 233, 2004.

[5] Pástor, M., Čarák, P., Gomory, I. "The assessment of the residual stresses influence on generation of the infringement in shape-complex supporting members", Strojnícky časopis - Journal of Mechanical Engineering 69 (1), pp. 85 - 96, 2019. DOI: 10.2478/scjme-2019-0007

[6] Paška, Z., Fojtík, F., Ferfecki, P. "Full field evaluation of the stress tensor components in 2D photoelasticity via computer software“. Strojnícky časopis - Journal of Mechanical Engineering 66 (2), pp. 63 - 66, 2016. DOI: 10.1515/scjme-2016-0019

[7] Achtelik, H., Gasiak, G., Grzelak, J. "Strength tests of axially symmetric perforated plates for chemical reactors: Part 1 - The simulation of stress state“, International Journal of Pressure Vessels and Piping 85, pp. 248 - 256, 2008.

[8] Achtelik, H., Gasiak, G., Grzelak J. "Strength tests of axially symmetric perforated plates for chemical reactors: Part 2 - Experiments", International Journal of Pressure Vessels and Piping 85, pp. $257-264,2008$.

[9] Ryś, J., Życzkowski, M. "Obliczanie tarcz z otworem kołowym w przypadku plastycznego wzmocnienia materiału“, Archiwum Budowy Maszyn. 18 (3), pp. 479 492, 1971. (in Polish). 
[10] Ryś, J. “Stan naprężeń, odkształceń, nośność sprężysta oraz sztywność tarczy z trzema otworami“", Czasopismo Techniczne 10, pp. 8 - 14, 1970. (in Polish).

[11] "Warunki Techniczne Dozoru Technicznego. Urządzenia Ciśnieniowe. Obliczenia Wytrzymałościowe. DT-UC-90IWO-O. UDT. “, Wydawnictwo Poligraficzne. 1991 (in Polish).

[12] Konieczny, M. "Wpływ geometrii otworu eliptycznego na rozkład naprężeń w płycie przy jednoosiowym obciążeniu“, Badania i Rozwój Młodych Naukowców w Polsce Nauki techniczne i inżynieryjne 1, 2019. ISBN: 978-83-66392-06-09 18-26 (in Polish)

[13] Konieczny, M., Gasiak, G. "State of Stress in the Plate with Slot at Biaxial Load", Conference Proceedings Fatigue Failure and Fracture Mechanics XXVII, 2018. ISSN: 978-0-7354-1750-2 1-9

[14] Konieczny, M., Gasiak, G. "Analysis of the impact of slot geometry on the stresses distribution in a plate of S235JR steel subjected at biaxial load“, Inżynieria Materiałowa - Material Engineering 6 (226), pp. 228 - 235, 2018.

[15] Jakubowicz, A., Orłoś, Z. "Wytrzymałość materiałów", WNT, Warszawa 1984 (in Polish)

[16] www.ctg.cornnell.edu/software/Franc2d for MS Windows 64b:f/ [acces from 12.10.2016].

[17] www.mesco.com.pl [acces from 15.04.2017].

[18] Nikolić, V., Dolicanin, Ć., Radojkowić, M. "Application of Finite Element Analysis of Thin Steel Plate with Holes“, Technical Gazette 18 (1), pp. 57 - 62, 2011.

[19] Gunwant, D., Singh, J. P. "Stress and Displacement Analysis of a Rectangular Plate with Central Elliptical Hole“, International Journal of Engineering and Innovative Technology 3 (3), pp. 387 - 392, 2013.

[20] Khechai, A., Tati, A. "Finite Element Analysis of Stress Concentrations in Isotropic and Composite Plates with Elliptical Holes“, Mechanical Engineering, pp. 427 - 436, 2015.

[21] Sharma, S. "Stress Concentration around Circular/Elliptical/Triangular Cutouts in Infinite Composite Plate", Proceedings of the World Congress on Engineering 3, pp. 1- 6, 2011. ISBN: 978-988-19251-5-2

[22] Rahman, S. "Stress Analysis of Finite Steel Plate with a Rectangular Hole Subjected to Uniaxial Stress Using Finite Element Method“, Journal of Marine Science: Research and Development 8 (3), pp. 1 - 6, 2018.

[23] Mohsin, N. R., Aoda, Y. F., Sayel, R. A. "Determination the effect of circular hole on the stress concentration for a plate subjected to uniaxial and biaxial stresses in tension and compression status“, International Journal for Management Science and Technology 3 (1), pp. 3 - 17, 2015.

[24] Bhandari, V. B. "Design of Machine Elements $3^{\text {rd }}$ edition". Tata McGraw-Hill, pp. 141 $150,2010$. 